
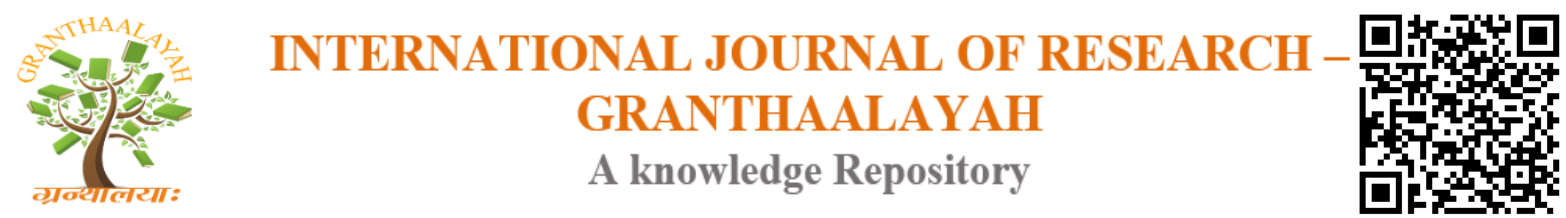

Science

\title{
AYURVEDIC APPROACH TO SHOTHA VYADHI WSR TO CHRONIC KIDNEY DISEASE
}

\author{
Vd. Pranali Thote ${ }^{\mathbf{1}}$, Vd Vivek Chandurkar ${ }^{2}$ \\ ${ }^{1}$ MD (Scholar) Kayachikitsa Department SGR Ayurved Collage, Solapur, India \\ ${ }^{2}$ Professor and HOD of Kayachikitsa Department, SGR Ayurved Collage, Solapur, India
}

\begin{abstract}
A 75 yrs male patient presenting with ubhaypadshoth (bilateral pedal edema), alpa udarvriddhi (abdominal distention), dourbalya (generalized weakness), agnimandya (loss of appetite) diagnosed as shotha vyadhi (odema) was brought to SSNJ Ayurved Hospital, Solapur. Patient was treated with an integrated approach of ayurveda. According to ayurveda, treatment of is vatanulomak aushadhi (laxative), agnideepan (increase appetite), balaprapti (stimulant for hepatic function), lepachikitsa, Proper diet (cow milk) and external application of shothahara lepa. Appreciable results were observed in the form of reduction in abdominal girth, decreased pedal edema,increased appetite, increased strength and significant changes in investigations.
\end{abstract}

Keywords: Ayurveda; Shotha; Virechana; Lepa.

Cite This Article: Vd. Pranali Thote and Vd Vivek Chandurkar. (2018). "AYURVEDIC APPROACH TO SHOTHA VYADHI WSR TO CHRONIC KIDNEY DISEASE.” International Journal of Research - Granthaalayah, 6(8), 51-56. 10.29121/granthaalayah.v6.i8.2018.1261.

\section{Introduction}

Edema (or Oedema) is the abnormal accumulation of fluid in certain tissues within the body. The accumulation of fluid may be under the skin - usually in dependent areas such as the legs (peripheral edema, or ankle edema), or it may accumulate in the lungs called pulmonary oedema.

Odema is one of the clinical menifestation of cardiac, liver and renal diseases. According to ayurveda odema is correlated with a vyadhi called shotha. shotha is a tridoshaj vyadhi. Such a vyaadhi in which there is a avarodha of swedovaha and udakavaha strotasa. Shotha (swelling) is a disease caused due to the Derangement of Doshas, which may appear in any part of the body.

Shotha is found as a main symptom in much number of ailments like Visarpa, Pidaka, Arbuda etc. But that which is going to spread vastly, which is nodulated, equal or unequal (Sama or Vishama) and particularly located dosha-samuha in the Twak (skin) and Mamsadi dhatus (tissue elements) is Shotha. Shotha, Shwayathu, Shopha and Utsedha were termed to be synonymous to word Shotha 
which means marked swelling of the skin in any place of the body. Shotha is classified into two types i.e. nija (endogenous) \& agantuja (exogenous).

Nija shotha manifested by aggravation of doshas, whereas aganthuja shotha is from external factors, which involves person coming in contact with harmful leaves, creepers etc. For example, drugs like kapikacchu (Mucuna Pruriens). This in modern parlance considered to be contact dermatitis. In the universe many herbs, shrubs tends to produce varied skin manifestation ${ }^{(1)}$

\section{Classification}

\section{According to Charaka}

Even though all the three doshas involved in the manifestation of all the types of the Shotha, it is on the basis of the predominance of the respective doshas that vataja, pittaja and kaphaja varieties of disease are determined and therapies are prescribed accordingly. All the varieties of the Shotha are considered to be tridoshaja i.e. they are caused by the vitiation of all the three doshas even so the causes of inflammation differs from one to another according to the particular dosha which is predominantly vitiated. The physician should therefore determine the line of treatment according to the predominance of one dosha or the other.
1) On the basis of Dosha
a) Vataja
b) Pittaja
c) Kaphaja
2) On the basis of Karana
a) Nija
b) Agantuja
3) On the basis of Sthana
a) Ekangaja
b) Sarvangaja.

\section{According to Sushruta}

Shotha develops from the six factors Vataja, Pittaja, kaphaja, Raktaja, Sannipataja and Agantuja. Depending upon signs, symptoms and treatment earlier six types has been explained but sarvasara that is the shotha which spread all over the body are of 5 types that is Vataja, Pittaja, kaphaja, Sannipataja and Vishaja. ${ }^{(2)}$

According to Vagbhata \& Madhavakara Based on different causes and symptoms it is of nine types from each dosha separately, from the combination of two doshas and from the combination of all them, from trauma/injury and from the poison. Mainly, it is of two types

a) Nija, Agantuja

b) Sarvanga, Ekanga

It is known to be of three types
a) Pruthu (hard)
b) Unnata (raised/elevated)
c) Grathita (glandular)

\section{Aims and Objecctives}

Ayurvedic approach to shotha vyadhi wsr to chronic kidney disease. 


\section{Materials and Methods}

\section{A Case Report}

A 75yrs male Hindu patient brought by his relatives to Seth Sakharam Nemchand Ayurved Hospital, Solapur belonging to the middle socio economic class presenting with complaints of Ubhayapadashotha, alpa udaravridhi (increased abdominal girth), Kshudha mandhya (decreased appetite),Aruchi, panduta(pallor), Dourbalya (general weakness), and Krishna varna (bilateral pedal oedema and discolouration), mukhashushkata ,trushna,since 6 months.

\section{On Examination}

1. General condition of patient is moderate

2. Pulse rate: $78 / \mathrm{min}$

3. B.P.- $130 / 80 \mathrm{mmofHg}$

4. eyes-Pallor

6. Weight- $38 \mathrm{~kg}$, Height- $164 \mathrm{~cm}$

7. $\mathrm{RS}-\mathrm{AE}=\mathrm{BE}$ clear

CVS - S1 S2 normal,no abnormal sound

CNS - well oriented.

8. P/A - Abdomen was mild distended with bulging of flanks.

On palpation liver is not palpable.

9. Bipedal pitting edema present.

\begin{tabular}{|c|c|c|}
\hline $\begin{array}{c}\text { Bipedal oedema } \\
\text { Measurement }\end{array}$ & Before treatment & After treatment \\
\hline Circumferance at ankle region. & $25 \mathrm{~cm}$ circumferance & $22 \mathrm{~cm}$ circumferance \\
\hline
\end{tabular}

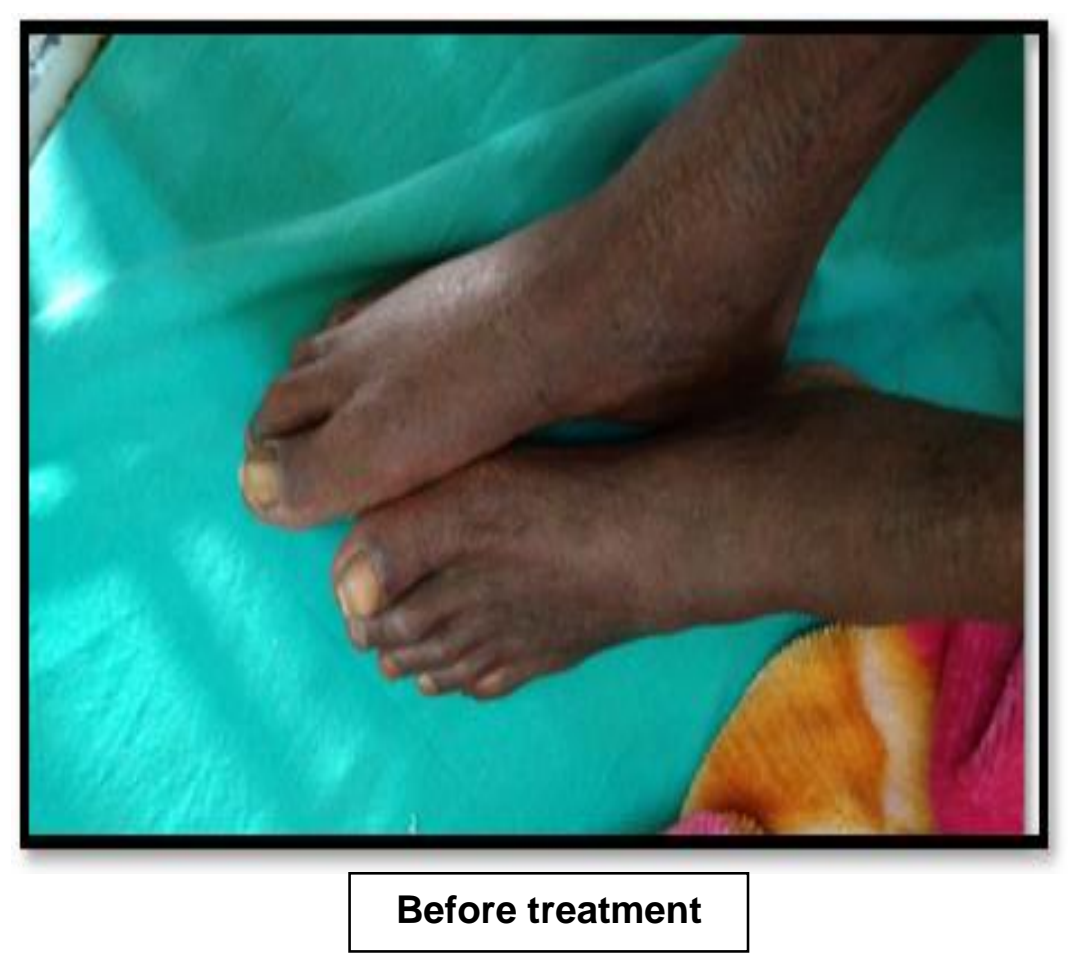




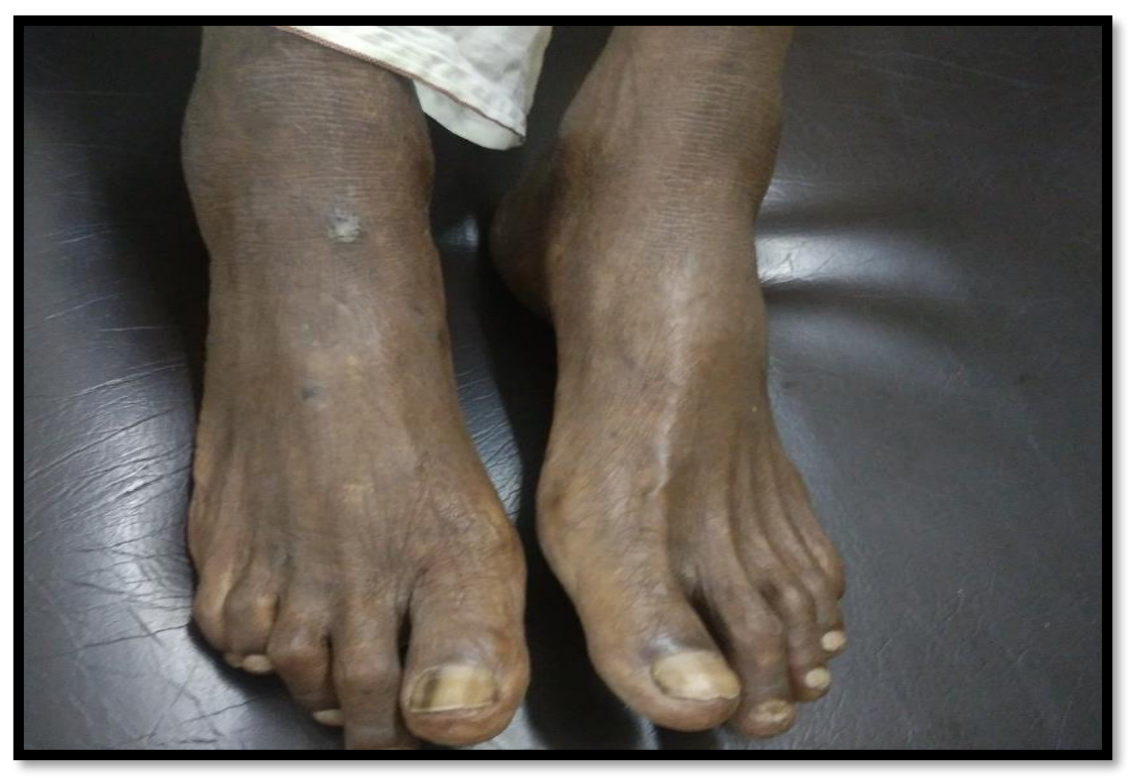

\section{After treatment}

\section{Ashtavidh Pariksha}

1. Nadi - Vatpradhan pitta

2. Mala - malavshtambha (occasional)

3. Mutra -4 to 5 times/day

4. Jivha-sama

5. Shabd - ksheen

6. Sparsh - anushana

7. Druk - panduta

8. Akriti -krusha

9 Srotodushti: Rasavahasrotas, Annavahasrotas, Udakvahasritas, Pranavahasrotas.

\section{Investigations}

$\mathrm{CBC}$

serum creatinine

Urine analysis

\section{Past History}

No H/O of DM, HTN, T.B, Asthma or any major illness.

No H/O of any Surgery.

\section{Treatment Approach}

Chandrprabha vati 1 gm twice daily Punarnavasava $20 \mathrm{ml}$ (twice daily). Sarvatobhadra ras $250 \mathrm{mg}$ twice daily Kwatha of punarnava, gokshura, guduchi, shunthi, haritaki each taken $2 \mathrm{gm}$ and $80 \mathrm{ml}$ water is added and boiled upto $20 \mathrm{ml}$ remained. Arogyavardhini rasa $1 \mathrm{gm}$ twice daily 
Application of lepa on odematous part (ubhay paadpradesh)

Maintain i/o chart daily.

\section{Discussion}

Review of pathogenesis of shoth vyadhi reveals that there is vitiated agni causing the imbalance of tridoshas due to mithya aharvihara like excessive intake of, tikshna, guru abhishyandi ahar sevan, krush akruti, panchkarma mithyopchar which vitiates the tridoshas and it results in Nij shotha.(1)

Classics have focused on the agnideepan and paachan, sanshodhan karma which depends on the dosholbanata and bala of that rugna. acharya charak has emphasized on the use of agnideepan, paachan, trushna - prashaman, langhan, dosh shodhan and shaman chikitsa which is according to doshadhikya in that vyadhi and rugna bal.(1)

Shothahar kwatha contains punarnava, gokshura, guduchi, shunthi, haritaki, which is mainly vatshamak, shothahar, agnideepak, vatanulomak, kledagna, mutral, properties. chandraprabha vati and sarvatobhadra vati both are mainly acts on mutravaha strotasa and it is balya for it. Punarnavasava is acts as shothaghna and results in decreased shotha.(3-4)
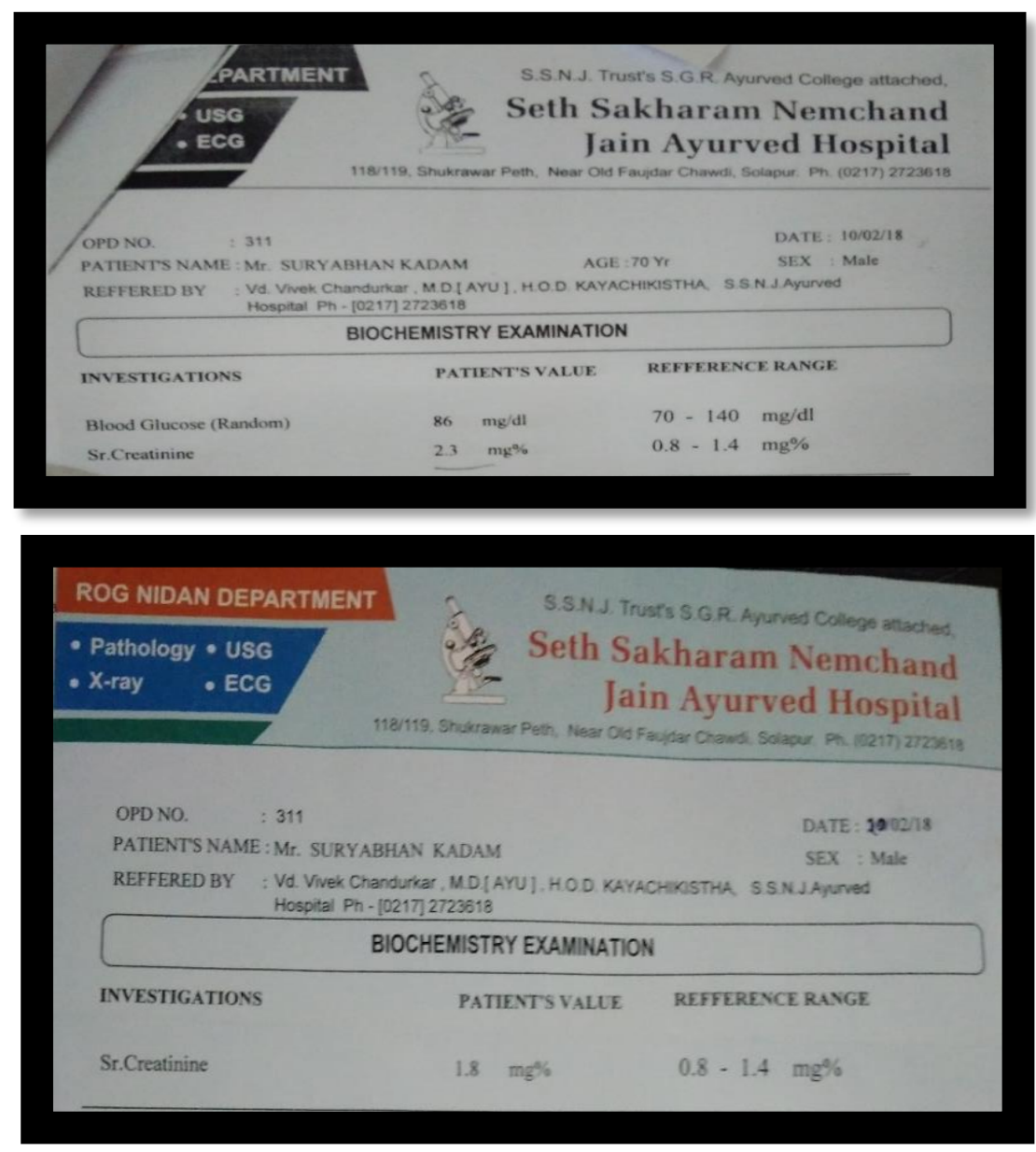


\begin{tabular}{|l|c|c|}
\hline \multicolumn{1}{|c|}{ Name of investigation } & Before treatment & After treatment \\
\hline Serum creatinine & $2.3 \mathrm{mg} / \mathrm{dl}$ & $1.8 \mathrm{mg} / \mathrm{dl}$ \\
\hline Urine protein & Present & $\mathrm{Nil}$ \\
\hline
\end{tabular}

\section{Conclusion}

Shothahar, deepan, paachan, mutral aushadhi provided better results in management of shotha vyadhi by improving both subjective and objective parameters. It can also help shotha patient to live a better quality of life.

\section{References}

[1] Dr Tripathi B (2013). Charak Samhita, hindi commentary, Part 1\& 2, Varanasi, Chaukhamba Surbharti Prakashan. (C.S.SU.18/6) Page No.366.

[2] Sharma P (2005). Sushrut Samhita, with English translation of text \& Dalhans commentary, Volume 1\& 2 .Varanasi, Chaukhamba Vishwabharti.(S.S.chi.23) Page No.485.

[3] Rasatantrasaar and siddhaprayog sangraha pratham khanda, chaukhamba prakashana,varanasi.page no 310 to 312 .

[4] Rasatantrasaar and siddhaprayog sangraha pratham khanda, chaukhamba prakashana,varanasi.page no 381.

*Corresponding author.

E-mail address: prannuthote@ gmail.com 